\title{
PEMETAAN PANAS PENYERAPAN RADIASI TERAHERTZ (THz) DALAM JARINGAN BIOLOGI PADA SAPI
}

\author{
Malik Usman ${ }^{1 *}$, Tobing Okta ${ }^{1}$, Hamdi $M^{1}$, Walfred Tambunan ${ }^{1}$ \\ ${ }^{1} J u r u s a n$ Fisika Fakultas Matematika dan Ilmu Pengetahuan Alam, Universitas Jambi \\ ${ }^{*}$ E-mail : usman.malik@lecturer.unri.ac.id
}

\begin{abstract}
Abstrak
Kajian pemetaan panas penyerapan radiasi THz terhadap jaringan sapi telah dilakukan untuk menentukan temperature dan warna kontur dari rasio kedalaman jaringan biologi sapi yaitul emak, kulit, tumor dan otot. Pemetaan ini dilakukan dengan menggunakan metode komputasi duadimensi dengan Software Wolfram Mathematica 8. Padajaringan lemak, dengan daya radiasi $\mathrm{THz} 50 \mathrm{~mW}$, dihasilkan rasio kedalaman sebesar 0,264 dan $T=6,6 \circ \mathrm{C}$. Jaringan kulit dengan daya $75 \mathrm{~mW}$, dihasilkan rasio kedalaman sebesar 0,435 dan $T=11$ oC, jaringan tumor dengan daya $100 \mathrm{~mW}$ dihasilkan rasio kedalaman sebesar 0,646 dan $\mathrm{T}=16,5 \mathrm{oC}$, jaringan tumor dengand aya $150 \mathrm{~mW}$, rasio kedalaman yang dihasilkan adalah 0,836 dan $T=21$ oC. Hasil penelitian menunjukkan bahwa jaringan lemak memiliki tingkat produksi panas tinggi diantara jaringan lainnya. Hal ini disebabkan karena jaringan lemak memiliki kandungan air yang lebih banyak dan fibrasi yang lebih cepat. Hasil perbandingan antara eksperimen dan komputasi temperature dalam rasio kedalaman penyerapan radiasi $\mathrm{THz}$ terhadap jaringan biologis sapi menunjukkan hasil yang akurat,yaitu dengan persentase ketidakpastian sebesar $0.08 \%$.
\end{abstract}

Kata kunci : Radiasi Terahertz (THz), Software Wolframe Mathematica 8, Jaringan Biologi, Pemetaan Panas, Penyerapan Radiasi

\begin{abstract}
[Titel : Heat Mapping of Terahertz (Hz) Radiation Absorption in Cow Biological Tissue] Thermal Mapping simulation of THz Radiation Absorption of cow's biological tissue has been done to determine the temperature and color of the contours from the depth ratio of each tissue which is fat, skin, tumor and muscle tissue by using two-dimensional computation method with Software Mathematica 8. Fat tissue uses $50 \mathrm{~mW}$ power, produces ratio 0,264 with yellow contour produces $T=6,6 \circ C$, skin tissue with $75 \mathrm{~mW}$ power produces ratio 0,435 with green contours produces $T=11$ oC, tumor tissue with $100 \mathrm{~mW}$ power, produces ratio 0,646 with blue contours produce $T=$ $16,50 \mathrm{C}$, tumor tissue with $150 \mathrm{~mW}$ power, produces ratio 0,836 with purple contours produces $T=21 \mathrm{oC}$, each contours color indicate that fat tissue has high thermal productivity level among skin, tumor and muscle tissue because fat contains more water and fast to calibrate. The result of experimental and computational temperature comparison in the depth ratio of THz radiation absorption of cow's biological tissue indicate $0,08 \%$ of uncertainty percentage.
\end{abstract}

Keywords : Terahertz (THz) Radiation, Software Mathematica 8, Biological Tissue, Thermal Mapping, Radiation Absorption.

\section{PENDAHULUAN}

Radiasi terahertz adalah satu dari daerah spektrum elektromagnetik yang berhubungan dengan proses molekul spesifik yang mempunyai frekuensi minimum $0.1 \mathrm{THz}$. Hal ini sebagai proses molekular dari rotasi molekul-molekul poliatomik untuk rotasi molekul kecil dan vibrasi ikatan fleksibel (Luca dan dkk,2014) .
Radiasi terahertz berinteraksi dengan jaringan biologi dan memiliki hubungan dengan teorema hamburan optik yang menggambarkan persamaan transpot poton yang dinyatakan dengan persamaan

$(s . \nabla) L(\bar{r}, \hat{s})=\frac{\mathrm{d} \mathbf{L}}{\mathrm{ds}}=-\mu_{t} \mathrm{~L}(\overline{\boldsymbol{r}}, \hat{\boldsymbol{s}})+\mu_{S} \int_{4 \pi} \mathbf{p}\left(\hat{\boldsymbol{s}}, \hat{s}^{\prime}\right) \mathbf{L}\left(\overline{\boldsymbol{r}}, \hat{s}^{\prime}\right) \mathbf{d} \omega^{\prime}$ 
dengan cross section penyerapan radiasi $\mathrm{THz}$ yang berinteraksi dengan jaringan biologi dinyatakan dengan persamaan penyerapan penampang $\sigma a$ yaitu :

$$
\sigma_{a}=\frac{P_{a}}{S}
$$

Dimana $\sigma_{a}$ adalah koefisien penyerapan, $P_{a}$ adalah daya penampang, dan $S$ adalah jarak.

Penyerapan panas radiasi terahertz berkaitan dengan penyerapan energy radiasi dan konduktivitas termal, dimana radiasi yang dipancarkan oleh sebuah benda sebagai akibat suhunya disebut radiasi panas (radiasi termal). Begitu suhu benda di tingkatkan, intensitas relatif dari spectrum cahaya yang dipancarkannya berubah (Hamdi dan Usman, 2015).Laju perpindahan panas yang terjadi pada perpindahan panas konduksi adalah berbanding dengan gradien suhu normal sesuai dengan persamaan berikut:

$$
\mathrm{Q}_{\mathrm{k}}=-k A \frac{\mathrm{dT}}{d X}
$$

Dimana Q adalah laju perpindahan panas (kj / det, $\mathrm{W}$ ) sementara $\mathrm{k}$ adalah konduktifitas termal $\left(\mathrm{W} / \mathrm{m} .{ }^{\circ} \mathrm{C}\right)$ kemudian A adalah luas penampang $\left(\mathrm{m}^{2}\right)$ selanjutnya $\mathrm{dT}$ adalah perbedaan temperatur $\left({ }^{\circ} \mathrm{C},{ }^{\circ} \mathrm{F}\right.$ ) sementara adalah perbedaan jarak $(\mathrm{m} /$ det $)$ dan $\Delta \mathrm{T}$ adalah perubahan suhu $\left({ }^{\circ} \mathrm{C},{ }^{\circ} \mathrm{F}\right)$.

Persamaan diferensial parsial untuk menyatakan perpindahan panas dua dimensi tersebut adalah (Buchori, 2000).

$$
p C_{P} \frac{\partial T}{\partial t}=\lambda\left[\frac{\partial^{2} T}{\partial x_{2}}+\frac{\partial^{2} T}{\partial y_{2}}\right]
$$

Syarat batas $t \geq 0$ dan $0 \leq x, y \leq 1$ yang mewakili konduksi panas dalam domain dua dimensi. Kondisi batas yang sedemikian rupa sehingga suhu U, sama dengan 0 pada semua tepi domain: $T(x=0, y, t=$ $0)$ dan $T(x=1, y, t=0)$ untuk $t \geq 0$, sementara untuk Tu $(x=0, y, t=0) \quad$ dan $T u(x=$ $1, y, t=0)$ untuk $t \geq 0$

\section{METODE PENELITIAN}

Berikut ini diagram alir yang menunjukkan prosedur yang dilakukan dalam penelitian ini:

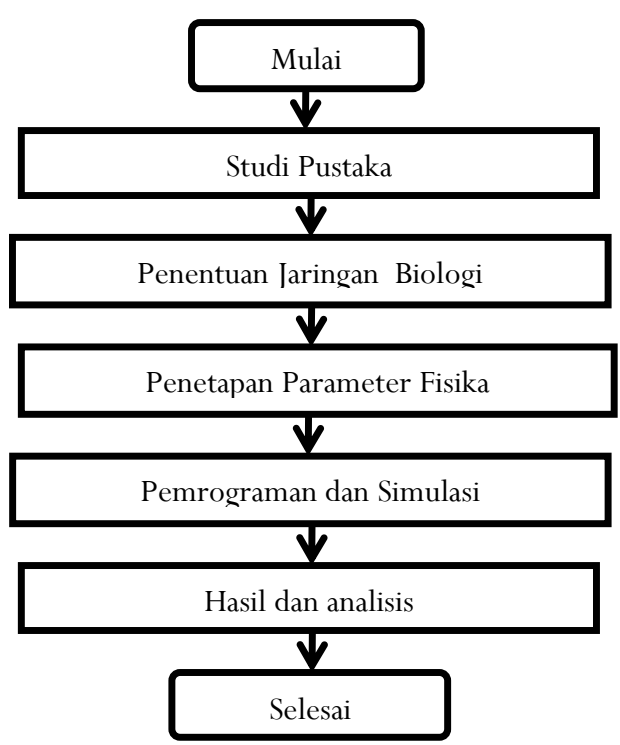

Gambar 1. Prosedur penelitian

Simulasi pada penelitian ini menggunakan impelentasi matematika dan modeling yang akan disimulasikan adalah modeling pada pemetaan panas penyerapan radiasi $\mathrm{THz}$ jaringan yaitu konduktivitas panas, koefisien penyerapan radiasi, densitas jaringan dan koefisien hamburan rendah. Proses pemodelan yang pertama memasukkan rasiowaktu pada setiap jaringan dengan daya yang berbeda setiap masingmasing jaringan.

Berikut ini adalah diagram alir yang menunjukkan komputasi numerik terhadap pemetaan panas penyeraapan radiasi $\mathrm{THz}$ :

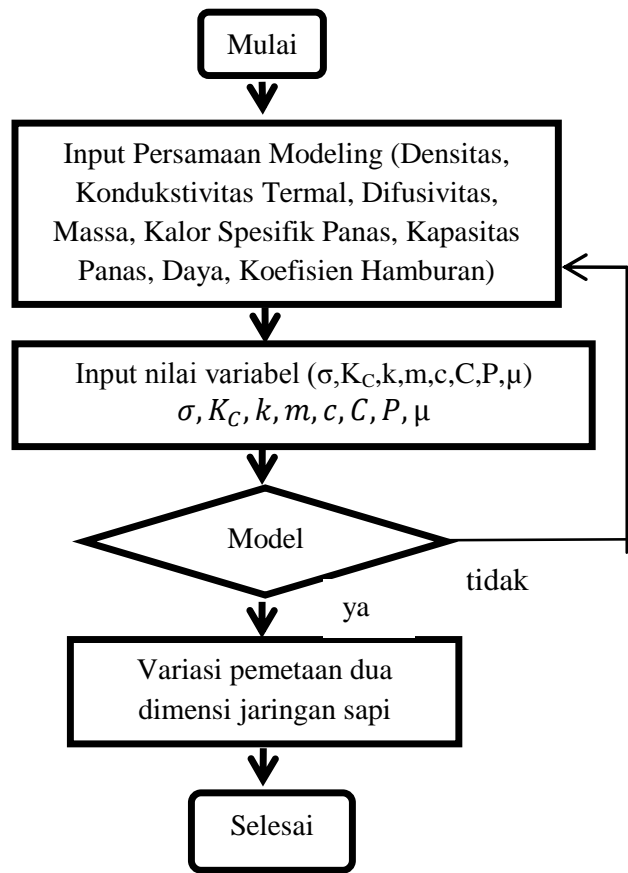

Gambar 2. Diagram alir simulasi pemetaan panas penyerapan radiasiTHz 
Komputasi numerik terhadap pemetaan panas penyerapan radiasi $\mathrm{THz}$ dilakukan untuk beberapa eksperimen jaringan dengan inputan daya yang berbeda.

\section{HASIL DAN PEMBAHASAN}

\section{Pemetaan Distribusi Panas Pada} Kedalaman Permukaan Jaringan Biologis Pada Sapi

Pemetaan konduksi panas teknik dua dimensi digunakan untuk mengetahui temperature dan warna kontur dari rasio kedalaman pada jaringan sapi meliputi antara lain: jaringan lemak, jaringan kulit, jaringan otot dan jaringan tumor.

Berikutadalah pemetaan panas masingmasing jaringan pada sapi:

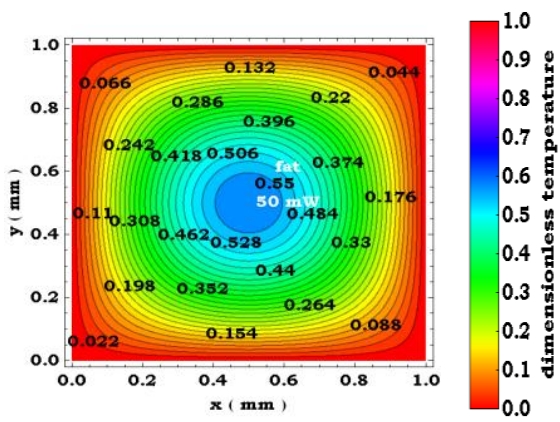

(a)

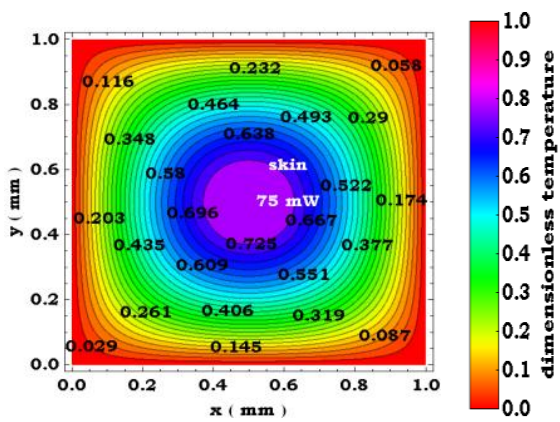

(b)

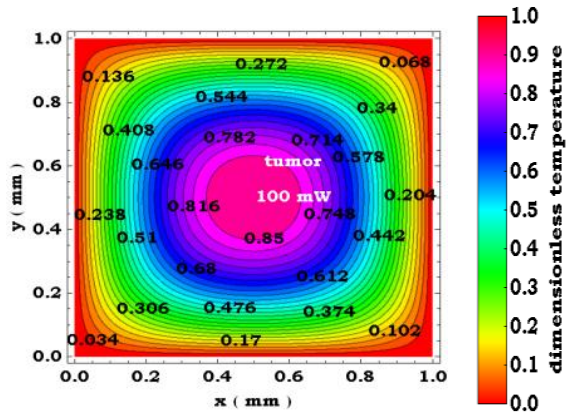

(c)

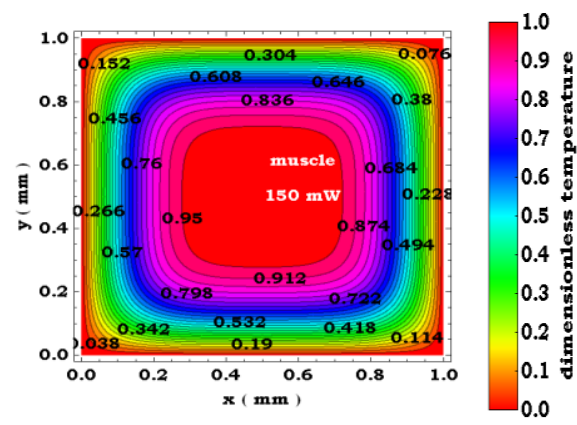

(d)

Gambar 4. Pemetaan panas dengan rasio warna pada (a) jaringan lemak (b) jaringan kulit (c) jaringan tumor (d) Jaringan otot

Kontur warna yang menunjukkan temperatur rendah terletak pada rasio warna 0.1 , sementara temperatur tinggi berada pada rasio waktu 1.0. Hasil pemetaan panas dari masing-masing jaringan terlihat bahwa pada daya yang rendah sebesar $50 \mathrm{~mW}$ jaringan lemak lebih mudah menyerap radiasi dan memiliki temperatur yang rendah dibandingkan dengan jaringan kulit, tumor dan otot,ini terlihat dari kontur berwarna orange yang lebih dominan.

\section{Perbandingan Hasil Eksperimen Temperatur Pada Kedalaman Rasio Dengan Hasil Komputasi}

Temperatur jaringan hewan padasapi dipengaruhi oleh kedalaman rasio. Hasil yang diperolah dari Gambar 1, Gambar 2, Gambar 3, Gambar 4 adalah hasil dari komputasi dalam bentuk pemetaan. Hasil pemetaan tersebut dibuat dalam bentuk tabel, kemudian dibandingan dengan hasil eksperimen yang dilakukan oleh penelitian sebelumnya.

Berikut ini adalah hasil tabel data perbandingan temperature eksperimen dan pemodelan:

Tabel 1.Data perbandingan nilai temperatur hasil komputasi dan eksperimen pada jaringan lemak sapi. 


\begin{tabular}{cccccc}
\hline $\mathrm{I}_{\mathrm{W}}$ & $\mathrm{I}_{\mathrm{k}}$ & $\mathrm{T}_{\mathrm{x}}\left({ }^{0} \mathrm{C}\right)$ & $\left.\mathrm{T}_{\mathrm{k}}{ }^{(} \mathrm{C}\right)$ & $\mathrm{T}_{\mathrm{els}}\left({ }^{\mathrm{C}} \mathrm{C}\right)$ & \% Kesalahan \\
\hline 0.1 & 0.11 & 25 & 2.75 & 2.75 & 0 \\
0.2 & 0.242 & 25 & 6.05 & 6.05 & 0 \\
0.3 & 0.352 & 25 & 8.8 & 8.79 & 0,1 \\
0.4 & 0.462 & 25 & 11.55 & 11.54 & 0,09 \\
0.5 & 0.506 & 25 & 12.65 & 12.64 & 0,08 \\
0.6 & 0.55 & 25 & 13.75 & 13.74 & 0.07 \\
\hline
\end{tabular}

Tabel 2.Data perbandingan nilai temperatur hasil komputasi dan eksperimen pada jaringan kulit sapi.

\begin{tabular}{cccccc}
\hline $\mathrm{r}_{\mathrm{W}}$ & $\mathrm{r}_{\mathrm{k}}$ & $\mathrm{T}_{\mathrm{x}}\left({ }^{0} \mathrm{C}\right)$ & $\mathrm{T}_{\mathrm{k}}\left({ }^{0} \mathrm{C}\right)$ & $\mathrm{T}_{\text {eks }}\left({ }^{0} \mathrm{C}\right)$ & \% Kesalahan \\
\hline 0.1 & 0.116 & 25 & 2.9 & 2.90 & 0 \\
0.2 & 0.261 & 25 & 6.53 & 6.52 & 0,1 \\
0.3 & 0.348 & 25 & 8.7 & 8.69 & 0,1 \\
0.4 & 0.406 & 25 & 10.15 & 10.14 & 0,09 \\
0.5 & 0.551 & 25 & 13.78 & 13.76 & 0,1 \\
0.6 & 0.637 & 25 & 15.93 & 15.91 & 0,1 \\
0.7 & 0.725 & 25 & 18.13 & 18.11 & 0,1 \\
\hline
\end{tabular}

Tabel 3.Data perbandingan nilai temperatur hasil komputasi dan eksperimen pada jaringan tumor sapi.

\begin{tabular}{cccccc}
\hline $\mathrm{r}_{\mathrm{W}}$ & $\mathrm{r}_{\mathrm{k}}$ & $\mathrm{T}_{\mathrm{x}}\left({ }^{0} \mathrm{C}\right)$ & $\mathrm{T}_{\mathrm{k}}\left({ }^{0} \mathrm{C}\right)$ & $\mathrm{T}_{\text {eks }}\left({ }^{0} \mathrm{C}\right)$ & \% Kesalahan \\
\hline 0.1 & 0.136 & 25 & 3.4 & 3.40 & 0 \\
0.2 & 0.238 & 25 & 5.95 & 5.95 & 0 \\
0.3 & 0.306 & 25 & 7.65 & 7.64 & 0,1 \\
0.4 & 0.476 & 25 & 11.9 & 11.89 & 0,08 \\
0.5 & 0.544 & 25 & 13.6 & 13.59 & 0,07 \\
0.6 & 0.612 & 25 & 15.3 & 15.29 & 0,06 \\
0.7 & 0.714 & 25 & 17.85 & 17.84 & 0,06 \\
0.8 & 0.748 & 25 & 18.7 & 18.69 & 0.05 \\
0.9 & 0.85 & 25 & 21.25 & 21.23 & 0.09 \\
\hline
\end{tabular}

Tabel $\overline{\text { 4.Data perbandingan nilai temperatur }}$ hasil komputasi dan eksperimen pada jaringan otot sapi.

\begin{tabular}{cccccc}
\hline $\mathrm{r}_{\mathrm{w}}$ & $\mathrm{r}_{\mathrm{k}}$ & $\mathrm{T}_{\mathrm{x}}\left({ }^{0} \mathrm{C}\right)$ & $\left.\mathrm{T}_{\mathrm{k}}{ }^{0} \mathrm{C}\right)$ & $\left.\mathrm{T}_{\mathrm{eks}}{ }^{0} \mathrm{C}\right)$ & \% Kesalahan \\
\hline 0.1 & 0.152 & 25 & 3.8 & 3.80 & 0 \\
0.2 & 0.266 & 25 & 6.65 & 6.64 & 0,1 \\
0.3 & 0.342 & 25 & 8.55 & 8.54 & 0.1 \\
0.4 & 0.494 & 25 & 12.35 & 12.34 & 0,08 \\
0.5 & 0.532 & 25 & 13.3 & 13.29 & 0,07 \\
0.6 & 0.646 & 25 & 16.15 & 16.14 & 0,06 \\
0.7 & 0.722 & 25 & 18.05 & 18.04 & 0,06 \\
0.8 & 0.836 & 25 & 20.9 & 20.88 & 0,05 \\
0.9 & 0.91 & 25 & 22.75 & 22.73 & 0,09 \\
1 & 0.95 & 25 & 23.75 & 23.73 & 0,08 \\
\hline
\end{tabular}

Hasil perbandingan temperature dari setiap jaringan dengan daya yang bervariasi dan range frekuensi yang rendah $0.1 \mathrm{THz}$ setiap jaringan yang menyatakan bahwa frekuensi berbanding terbalik dengan temperature. Perbandingan temperature setiap jaringan diperoleh persentase ketidakpastian yang cukup akurat sebesar $0.08 \%$.

\section{SIMPULAN DAN SARAN}

Berdasarkan hasil diperoleh dapat diambil kesimpulan sebagai berikut:

1. Jaringan lemak lebih mudah menyerap radiasi dikarenakan lemak mengandung air lebih banyak, lebih mudah berfibrasi, lemak juga memiliki karakteristik struktur penyusun jaringan yang berbeda setiap jaringan dan memiliki temperatur yang rendah dibandingkan dengan jaringan kulit, tumor dan otot.

2. Hasil perbandingan temperature eksperimen dengan pemodelan diperoleh persentase ketidakpastian sebesar $0.08 \%$, ini menunjukkan bahwa hasil pemodelan memiliki tingkat keakuratan yang tidak jauh berbeda dengan hasil eksperimen.

3. Daya yang rendah pada suatu jaringan akan menghasilkan temperatur yang rendah juga, maka dari daya berbanding lurus dengan temperatur.

\section{DAFTAR PUSTAKA}

Hamdi, Muhamad dan Usman Malik. 2015. "Prediksi Transfer Panas Radiasi Terahertz Dalam Jaringan Biologi Menggunakan Metode Komputer Analog”. Prosiding Seminar Nasional Fisika (E-Journal)volume IV.

L. Buchori, Y. Bindar dan Istadi. (2000). "Komputasi Perpindahan Panas Konduksi Dua Dimensi Untuk Konveksi Dan Radiasi Termal”. Teknik Kimia, Universitas Diponegoro, Semarang, p. F5.1-F5.8

Pietro Michelia, dan Luca Mari. 2014. The theory and practice of performance measurement: Management Accounting Research 147156 